УДК 82.0'02.091+821.161.1.091

https://doi.org/10.33989/2524-2490.2020.33.228207

NATALIIA TARASOVA

ORCID 0000-0001-9712-9465

(Полтава) (Poltava)

Place of work: Poltava V.G. Korolenko National Pedagogical University

Country: Ukraine

Email: taras0va040816@gmail.com

\title{
COMPARATIVE ANALYSIS OF THE TRILOGY THE ORESTEIA BY AESCHYLUS AND THE NOVEL CRIME AND PUNISHMENT BY F. DOSTOEVSKY
}

\begin{abstract}
У статті здійснено спробу компаративного аналізу трилогї «Орестея» Есхіла та роману «Злочин і кара» Ф. Достоєвського. Відзначено, щцо компаративістика досліджуе історичні процеси диференціаціиї й розходження та збіги й уніфікації літературних явищ, а одним із ї̈ завдань е формування - на тлі існуючих різниць і розбіжностей - синтетичного образу літератури. Більше того, вона об'єднуе в одне цุіле набуті в дослідженнях знання про літературу, про ї̈ місие в культурі та у відповідному цุивілізаційному колі. 3'ясовано, ще в основі компаративного аналізу лежить дослідження генетичних та контактних зв'язків. Зіставлення трилогії Eсхіла «Орестея» та роману Ф. Достоєвського «Злочин $і$ кара» проводихося на рівні генетичних зв'язків і базувалося на тому підрозділі компаративістики, який зосереджуе в собі різноманітні емпіричні дослідження, що стосуються впливів і відношень окремих літератур. Виявлено схожість творів у тематичному, ідейному, проблемному аспектах, почасти - у жанровому; відмінності відзначаємо в змалюванні героїв, стильовому розмайтті, структурних особливостях.
\end{abstract}

Ключові слова: компаративний аналіз; тема; ідея; проблематика; жанр; структура; стиль.

A modern literary criticism is actively interested in comparative studies, which studies the relationships, interactions and interactions of literatures around the world. The term comparative studies comes from the Latin words compare, comparatio, comparativus, which mean the action of comparison, comparative attitude and result (Nalyvayko, 2006, p. 15). Scientific comparative studies has existed almost since the advent of literature. Even in the classical era of ancient Greek literature, in the 6-5 centuries BC, there is a comparison of literary phenomena in works of art. Thus, in Aristophanes' comedy The Frogs, a dispute unfolds between Aeschylus and Euripides, which compares their creative positions on the fundamental question: how to portray a person by means of words - that is, real creative programs are proposed. We also find elements of comparative studies in Aristotle's famous Poetics: in the section on tragedy, there are also comparative points at the level of comparisons between tragedy and epic, epic and history.

As a science, literary comparative studies began to take shape in the 19th century. However, literary comparative studies, as a branch of literary science, is not limited to a reflection on comparisons made with research purposes. Its main purpose is the cognitive comprehension of "own", "someone else's" and general literary reality as a dynamic, internally differentiated and variable in its content and boundaries of "possible community", associated with many relationships with other areas of literature and culture (Ulitska, 2008, p. 518).

In other words, literary comparative studies examines the participation of stylistically, linguistically, culturally and ethnically different literatures - through their connections, interactions and collective configurations - in the formation of world literature and, on the other hand, the participation of world and regional cultures in the formation of in- 
dividual literatures, including primarily national literatures (Nalyvayko, 2006, p. 12). In its modern form, comparative studies is primarily a science of interactions, kinship, differences and typological correspondences of literary phenomena: individual works, individual and collective literary products, genres, styles, trends, eras, themes, national literatures, cultural and civilizational cultures and circles (Nikolenko, 2011, p. 16).

Traditionally, comparative analysis has been based on the study of genetic and contact relationships in the literature.

Genetic connections are connections between different literary phenomena that come from a common source, that is, phenomena related to their origin. They are studied at the thematic (themes, plots, motives), genetic (genera, genres, genre varieties) and mythological (components of a literary work or process) levels (Marchenko, 2005, p. 5). A typical example of the study of genetic connections is the study of "wandering" plots, i.e. those that arise in the mythology, folklore or literature of a particular country and spread to other countries.

Contact links are links between writers (schools, trends, literatures) that are documented. Their purpose is to document that a writer was aware of and influenced by another writer; that a certain motif or hero, a feature of the genre structure of a work or style is borrowed or introduced, inspired by the works of another writer (Nalyvayko, 2006, p. 15).

Unlike genetic bonds, which exist in different time planes, contact bonds mostly unfold synchronously.

Comparative studies, as a science, is divided into three main sections, which differ in problematics, subject and area of interest. The first section contains elements of methodological considerations on the topic of methods of comparison and the comparative method, which are used for cognitive purposes. The second section focuses on a variety of empirical studies that relate to the influences and interrelationships of individual literatures. The third section deals with the theory of comparative literature, which forms a synthetic image of literature and literary phenomena on the basis of research, conducted using comparative and some additional methods (Ulitska, 2008, p. 520).

In our opinion, the comparison of Aeschylus' trilogy The Oresteia and F. Dostoevsky's novel Crime and Punishment should be made at the level of genetic connections and based on the second subdivision of comparative studies, which "concentrates various empirical studies" that "concerning influences and mutual relations of separate literatures". We mean the ancient Greek and Russian literature, the connections that come from a common source (mythology) and are studied at the thematic (themes, motives) level. These are multinational works, close to the theme, idea, issues, etc.

A comparative analysis of the works of these different writers reveals a holistic vision of the world literary process.

We do not know any research on the creative connections between Aeschylus and F. Dostoevsky in modern literary studies. Therefore, the purpose of our work is an attempt to make a comparative analysis of the works of these writers at the ideological, thematic, genre, structural and stylistic levels.

At first glance, these works are completely different, but we find much in common when looking closer at them.

The problem of bloodshed is the main one in Aeschylus' trilogy The Oresteia and F. Dostoevsky's novel Crime and Punishment. In Aeschylus's The Oresteia, such eternal problems are raised as the choice between duty and family feelings, the need for personal responsibility for the decision made, and the realization of the disastrous consequences of war for both the victors and the vanquished. F. Dostoevsky's novel Crime and Punishment covers complex social, philosophical, ethical issues: the purpose and meaning of human existence, the clash of ideology and life, crime and punishment, the fall of the individual and spiritual rebirth. The leading idea of both works is not the call of people to physical struggle and blood, but the conversion to the commandment "Thou shalt not kill!". 
Aeschylus' trilogy The Oresteia is in three parts and includes plays: Agamemnon, The Libation Bearers (Those who sacrifice to the grave, or Sacrifice at the tomb), The Eumenides (Gracious Ones). The Oresteia is based on the Trojan cycle of myths, in particular on the dramatic history of the god-cursed house of the Atreides. The first play is the tragedy of murder, the second is revenge, and the third is trial and forgiveness. The whole trilogy shows how the divine will is manifested in the family of the criminal Atreides, the last representatives of which were Agamemnon and Orestes.

Crime and Punishment by F. Dostoevsky consists of six parts and an epilogue. The reader sees the scenes of the trial of Raskolnikov in two guises: moral and legal. Murder is considered in the background, and in the foreground there is an analysis of the psychological state of the individual, the moral face of the "criminal". The first three parts of the novel have motives of "condemnation", the next three - "justification". The novel consists of two parts, which are still defined as "for" and "against". In each part of the work Raskolnikov is compared with persons who shade any side of his personality.

In some comments, Crime and Punishment is called a tragedy novel, because there are common features with this genre. In F. Dostoevsky's version, the novel becomes a tragedy in epic form, as well as the trilogy of Aeschylus. It seems that Dostoevsky is reviving the art of the ancient tragedy of Aeschylus in the form of a modern novel.

Raskolnikov's story in our perception is a new interpretation of the Aeschylus' trilogy in the struggle against fate, although there is no evidence that F. Dostoevsky studied the Aeschylus' trilogy. The source of information for him was primarily the drama of the $18-19$ th centuries.

As for the theme, the leading theme of both works is the need to punish evil, revenge and evil. In the Aeschylus trilogy, the gods themselves watch closely and zealously for Orestes to take sacred revenge on his father's murderers. The fact is that the ancient Greek perceived being as a cosmic harmony, truth, justice, established by the gods. To do evil meant to break the established order. Punishment, revenge for evil, as the Greeks believed, restores the original harmony. The Greeks were also convinced that the soul of the slain, if not avenged, would fly around the world, and cause a lot of harm to relatives who did not take revenge for the blood, and people in general. Such a philosophy certainly encountered a significant obstacle. After all, he who avenges evil with violence, commits a crime himself, creates a new evil that requires another criminal. How to stop the growth of evil in this situation, the only way out is suffering. Therefore, in the tragedy of Aeschylus, Orestes suffers, because suffering itself is the thorny path that leads a person to understanding, wisdom, and harmony.

Raskolnikov's goal is also noble - in the long run to be useful, humiliated and disadvantaged. But the path to its implementation lies through crime. To kill to test yourself; to kill to seize money, thanks to their presence to complete university studies; to kill in order to exalt oneself, to rise above others, and then to do good.

The heroes of both works chose the wrong path to achieve the goal, so, in the end, did not reach it, and stopped halfway. They killed, and after this cruelty they felt the burden on their souls. Thus, the goal of each hero was a noble idea and a noble way of its implementation.

An attention in both works is focused on the psychological state of the characters, which is a real punishment for them. The heroes do not immediately repent of their crimes, but only over time. Raskolnikov understood the essence of his crime and repented only in hard labor. Aeschylus also emphasizes that not all people have the ability to attain wisdom and harmony through suffering, often, on the contrary, suffering leads to harm to others.

Both works have a happy ending. The Oresteia ends with a scene of reconciliation. Erinyes stop wanting blood after the trial of Orestes, which takes place in Athens. From vengeful goddesses they are transformed into merciful goddesses. In F. Dostoevsky's novel, Raskolnikov also repented and realized the essence of the sin committed. 
Finding out the peculiarities of the style of writers allows us to determine the peculiarities of the authors' worldview, the set of pictorial and expressive means and sociocultural conditions under the influence of which the artistic originality of each work is formed. The author's style is the set of features of creativity that distinguishes his works from the works of other writers. Style is a set of artistic features of a literary work. In a broader sense, style is also called a system of artistic means and techniques in the work of an individual writer, a group of writers (trend or direction), the whole literary era (Halych, \& Nazarets, \& Vasiliev, 2001, p. 344).

F. Dostoevsky's style is a style in which we clearly see the author's desire to develop the reader's ability to think independently. The writer does not agree, he hints, expresses inaccurately and at the same time with some impressive sophistication makes the reader think and draw their own conclusions. Among the classics of world literature, F. M. Dostoevsky deservedly holds the title of master in revealing the secrets of the human soul and creator of artistic thought. The novel Crime and Punishment opens a new, higher stage of Dostoevsky's work. Here he first appeared as the creator of a fundamentally new novel in world literature, which was called polyphonic one. All the artistic features and poetics of the novel Crime and Punishment are a means of revealing the special spirituality of Dostoevsky. Working on the novel, the writer mainly sought to trace the psychological process of the crime. That is why Crime and Punishment is considered a work in which the originality of the writer's psychology is most clearly reflected.

Aeschylus' trilogy The Oresteia, built with the help of ancient heroic images, cannot but have the monumental style which is usual for Aeschylus, and the accumulation of numerous horrors makes it pathetic. The style of the Aeschylus' tragedy is closely connected with the source of the tragedy, the cult of Dionysus, and the praise. Since the praise is originally a cult song in honor of the god Dionysus, which had a solemn and majestic character, the tragedy of Aeschylus close to it had a monumental style. The monumental element in the tragedy of Aeschylus arises from the use of mythology. Aeschylus raises issues of world historical significance: the struggle of patriarchy and matriarchy, the collapse of the communal and tribal system. The mythology associated with these historical events makes Aeschylus' artistic style monumental.

In addition, the cult of Dionysus was full of pathos, which inevitably influenced the style of the tragedy of Aeschylus: it is pathetic. The pathetic element of Aeschylus is very diverse: it is generally psychological, and especially prayerful, and majestic. The monumental and pathetic style of the Aeschylus tragedy, which had a close connection with the cult of Dionysus, is quite peculiar to the writer. To characterize the monumental and pathetic style, it is necessary to pay attention to the functioning of two main elements in the general style of tragedies. This style depicted the natural foundations of life, which were mentioned in the religion of Dionysus. Thus, in the works of Aeschylus, the monumental and pathetic style demonstrates the design of the foundations of life in clear images, which can be called plastic. In the tragedies of Aeschylus there is a figurative element of ancestral life, which can be seen in Erinyes. These are the most important forms of manifestation of the main monumental and pathetic style of Aeschylus. Mythology, which emerged on the basis of communal and tribal collectivism, could not create another style for the tragedies of Aeschylus.

We should note the significant similarity in the psychological picture of images. Thus, each of Dostoevsky's heroes in Crime and Punishment can be given its own verbal description, but the most expressive is the linguistic portrait of Raskolnikov. Dostoevsky with great skill showed the bifurcation of the personality of the protagonist of the novel, using different stylistic devices: fragmentary language Raskolnikov, disharmony of his language syntax, and most importantly - the contrast between external and internal form of the language of the hero. "Laws of the fourth dimension", where the earth's gravity ceases to operate, obeys everything in the style of the novel: portrait, landscape, place and time of action. The writer's special, unique rhythm fascinates the readers so much that they do not 
immediately appreciate every detail of the hero's portrait. The methods of creating a psychological image of the writer are extremely diverse. Despite the fact that Dostoevsky rarely used the portrait, he is considered a subtle and profound master of the portrait. The writer believed that a human is a very complex creature, and its appearance can not reflect its essence. More important for Dostoevsky is the costume of the hero or any detail in it that reflects the character. In the novel Crime and Punishment, the portrait serves to reveal the essence of a hero. Thus, in describing Svidrigailov, Dostoevsky used one, at first glance, insignificant detail: "His eyes were blue and looked cold, intent and thoughtful; lips were scarlet. In general, he was a well-preserved man and seemed much younger than his years" (Dostoevsky, 2009, p. 296). But thanks to this detail it is possible to present all Svidrigailov for whom everything is indifferent and to whom everything is allowed. The eyes play an important role in the portrait of all the protagonists of the novel; they can be used to learn the thoughts of the characters, to reveal their secrets. It is said about Dunya's eyes as follows: "She looked like her brother in face, but she could even be called a beauty. Her hair was dark blond, a little lighter than her brother's; eyes are almost black, sparkling, proud and at the same time sometimes, in minutes, unusually kind" (Dostoevsky, 2009, p. 252), and we read the following about Raskolnikov's eyes: "He was remarkably handsome, with beautiful dark eyes, dark brown, taller than average, thin and slender, but so poorly dressed that in such rags another person would be ashamed to go out into the street" (Dostoevsky, 2009 , p. 32). Sonya "was small in stature, about eighteen years old, thin, but rather pretty blonde, with wonderful blue eyes" (Dostoevsky, 2009, p. 231).

In The Oresteia, the image of Cassandra is decisively superior to anything that Aeschylus could be attributed to the realm of psychological realism. The complex of Cassandra's experiences, unprecedented in its tragedy, is depicted in Aeschylus not in epic descriptions, but in the form of a story of a herald or a transfer of feelings and moods of the choir: "Such a time will come; the defeated city of Priam will collapse" (Davnohretska trahediia, 2006, p. 120). They are given in themselves in all their eerie nudity and the sharpest; one might say burning, psychologism. Aeschylus' monumental and pathetic style reached here not only the image of individual psychology. Cassandra appears in all the fullness of human feelings and experiences, including all the strength and weakness of the human psyche, riot, helplessness, heroism and at the same time doom, which lost a person a minute before her death: "They laughed at me: I saw the fire, and you think that Troy really turned to dust" (Davnohretska trahediia, 2006, p. 125).

The language and style of the novel Crime and Punishment is natural and direct. According to some researchers, Dostoevsky's language loses in picturesqueness and visual aids. However, this is not the case, because Dostoevsky has his own, very specific, different from other writers of the 19th century, the manner of depiction. By seemingly inconspicuous accelerations and decelerations, rhythm, increase and decrease of speech, pauses, the author helps the reader to feel the invisible movement of life.

Aeschylus reveals his individuality in artistic language: he uses characteristic neologisms, colorful metaphors and descriptions. Accordingly, the language of ordinary people, which appears in his tragedies, is everyday and understandable (Pashchenko, 1981, p. 72).

Peculiarities of F. Dostoevsky's style are the synthesis of the novel and tragedy, the rapid development of the plot, the polyphony of the novel, the use of confession, the portrait description of the characters, the conciseness of the descriptions, and the deep psychologism.

Aeschylus' style has its own features: archaic compositional writing technique; appeal to different genres: oratorios with very spatial epic elements of drama, as well as rhetorical recitation; coverage of the theme of destiny and the meaning of God in people's lives; the presence of mythological, historical, philosophical, religious and autobiographical motives.

Thus, a comparative analysis of the trilogy The Oresteia by Aeschylus and the novel Crime and Punishment by F. Dostoevsky shows that when comparing the ideological, thematic, problematic, structural and stylistic aspects, the works are quite similar. According 
to a certain superficial similarity of the plots, a deep knowledge of human psychology, the inner world of the heroes and their unique individuality can be seen. The works differ radically based on sources of information, depicting the time and place of action, stylistic features. Despite the centuries between them, both works are relevant today, because the problem of crime, punishment for crime does not lose its position in a society with economic, social, political turmoil, ethnic conflicts, etc.

\section{СПИСОК ВИКОРИСТАНИХ ДЖЕРЕЛ}

Галич О., Назарець В., Васильев С. Теорія літератури : підручник для студ. філологічних спец. вищих закладів освіти. Київ : Аибідь, 2001. 488 с.

Гупало О.-Х. С. Образи природних стихій у романі Ф. М. Достоєвського «Злочин і кара». Молодий вчений. 2017. № 7 (47). С. 182-187.

Давньогрецька трагедія. Есхіл. Софокл. Еврипід / [пер.: Б. Тен, А. Содомора]. Харків : Фоліо, 2006. 479 c.

Достоевский Ф. М. Преступление и наказание : роман. Санкт-Петербург : Азбука-классика, 2009. 673 с.

Марченко Н. П. Наука, яка дедалі більше визначатиме методику викладання дітератури. Тема. 2005. № 1-2. С. 4-13.

Маслова Г. М. Вплив мовленнєвих жанрів на формування мовної особистості у романі Ф. М. Достоєвського «Злочин і кара». Наукові записки Національного університету «Острозька академія». Серія «Філологія». Острог : Вид-во НаУОА, 2019. Вип. 8 (76). С. 79-82.

Наливайко Д. С. Теорія літератури й компаративістика. Київ : Києво-Могилянська академія, 2006. 348 c.

Ніколенко О. М. Компаративний підхід у вивченні світової літератури у старших класах загальноосвітньої школи. Всесвітня література в середніх навчальних закладах Украйни. 2011. № 6. C. 16-23.

Пащенко В. І. Еллінський театр і його уславлені трагічні поети. Давньогрецька трагедія / пер. Б. Тен. Київ : Дніпро, 1981. С. 5-24.

Пушак Ю. В. Особливості компетентного читання творів Достоєвського в сучасній Україні (1991-2008). Вісник Аьвівського університету. Серія: Іноземні мови. 2011. Вип. 18. С. 233-240.

Уліцька Д. Література. Теорія. Методологія. Київ : Києво-Могидянська академія, 2008. 543 с.

\section{NATALIIA TARASOVA}

COMPARATIVE ANALYSIS OF THE TRILOGY THE ORESTEIA BY AESCHYLUS AND THE NOVEL CRIME AND PUNISHMENT BY F. DOSTOEVSKY

The article attempts to make a comparative analysis of the trilogy The Oresteia by Aeschylus and the novel Crime and Punishment by F. Dostoevsky. It is noted that comparative studies investigates the historical processes of differentiation and divergence, convergence and unification of literary phenomena, and one of its tasks is the formation - against the background of existing differences and disagreements - of a synthetic image of literature. Moreover, it integrates the knowledge gained in research about literature, its place in culture and in this circle of civilization. Comparative analysis has been found to be based on the study of genetic and contact relationships. The comparisons of Aeschylus' trilogy The Oresteia and F. Dostoevsky's novel Crime and Punishment were made at the level of genetic connections and were based on the subdivision of comparative studies, which concentrates various empirical studies on the influences and relationships of individual literatures. The similarity of works in thematic, ideological, problem aspects, partly - in genre is revealed; differences are noted in the portrayal of the characters, stylistic diversity, and structural features.

Key words: comparative analysis; theme; idea; problematics; genre; structure; style.

\section{REFERENCES}

Dostoevsky, F. M. (2009). Prestuplenie i nakazanie [Crime and Punishment]. Sankt-Peterburg: Azbukaklassika Publ [in Russian].

Halych, O., Nazarets, V., \& Vasiliev, E. (2001). Teoriia literatury [Theory of literature]. Kyiv: Lybid Publ [in Ukrainian].

Hupalo, O.-Kh. S. (2017). Obrazy pryrodnykh stykhii u romani F. M. Dostoievskoho "Zlochyn i kara" [Images of natural elements in Dostoevsky's novel Crime and Punishment]. Molodyi vchenyi [A young scientist], 7 (47), 182-187 [in Ukrainian]. 
Marchenko, N. P. (2005). Nauka, yaka dedali bilshe vyznachatyme metodyku vykladannia literatury [The science that will increasingly determine the method of teaching literature]. Tema [Topic], 1/2, 4-13 [in Ukrainian].

Maslova, H. M. (2009). Vplyv movlennievykh zhanriv na formuvannia movnoi osobystosti u romani F. M. Dostoievskoho "Zlochyn i kara" [The influence of speech genres on the formation of language personality in Dostoevsky's novel "Crime and Punishment"]. Naukovi zapysky Natsionalnoho universytetu Ostrozka akademiia. Ceriia "Filolohiia" [Scientific notes of the National University "Ostroh Academy". Philology Series] (Is. 8 (76, pp. 79-82). Ostroh: NaUOA [in Ukrainian].

Nalyvayko, D. S. (2006). Teoriia literatury y komparatyvistyka [Theory of literature and comparative studies]. Kyiv [in Ukrainian].

Nikolenko, O. M. (2011). Komparatyvnyi pidkhid u vyvchenni svitovoi literatury u starshykh klasakh zahalnoosvitnoi shkoly [Comparative approach in the study of world literature in senior classes of secondary school]. World literature in secondary schools of Ukraine [World literature in secondary schools of Ukraine], 6, 16-23 [in Ukrainian].

Pashchenko, V. (1981). Ellinskyi teatr i yoho uslavleni trahichni poety [Hellenic theater and its famous tragic poets]. In B. Ten (trans.), Davnohretska trahediia [Ancient Greek tragedy] (pp. 5-24). Kyiv [in Ukrainian].

Pushak, Yu. (2011). Osoblyvosti kompetentnoho chytannia tvoriv Dostoievskoho v suchasnii Ukraini (1991-2008) [Peculiarities of competent reading of Dostoevsky's works in modern Ukraine (1991-2008)]. Visnyk Lvivskoho universytetu. Seriia: Inozemni movy [Bulletin of Lviv University. Series: Foreign languages], 18, 233-240 [in Ukrainian].

Ten, B., \& Sodomora, A. (Trans.). (2006). Davnohretska trahediia. Eskhil. Sofokl. Evripid [Ancient Greek tragedy. Aeschylus. Sophocles. Euripides]. Kharkiv: Folio Publ. [in Ukrainian].

Ulitska, D. (2008). Literatura. Teoriia. Metodolohiia [Literature. Theory. Methodology]. Kyiv [in Ukrainian].

Отримано 27.10.2020 p. 